\title{
Adaptation of Fishermen "Kampung Laut" Cilacap Against Environmental Change
}

\author{
Muhammad Sholeh ${ }^{1}$, Bagja Waluya ${ }^{2}$, Amin $^{3}$ \\ \{muhsholeh@mail.unnes.ac.id $\left.{ }^{1}\right\}$ \\ ${ }^{1}$ Universitas Negeri Semarang, Indonesia \\ ${ }^{2}$ Universitas Pendidikan Indonesia, Indonesia \\ ${ }^{3}$ Universitas Islam 45 Bekasi, Indonesia
}

\begin{abstract}
The majority of "Kampung Laut" Communities Cilacap are fishermen as a legacy of livelihoods from previous generations. Fishermen are the most rational job choice because physically they live on the waters (stage houses) and directly interact with the sea. During its heyday the sea along the "Segara Anakan" yielded abundant results because the area became a meeting place for various types of fish originating from the Indonesian Ocean. Changes in the physical environment cause the fish catch to drop dramatically. Beautiful stories about the abundance of fish catches have ended, now fishermen are increasingly difficult to catch fish. The "Segara Anakan" area has changed, more precisely experiencing a decrease in carrying capacity because it is getting narrower, shallower, and the quality of its waters deteriorates. These changes are caused by several factors, both natural and due to the impact of human activities. This has a direct impact on the catch of local fishermen. These changes are a challenge for fishermen to continue to continue their profession. Various methods have been taken to ensure that environmental changes are not to be dealt with but faced. The adaptation of fishermen to changes in the physical environment is manifested in various forms that show their enthusiasm to maintain loyalty as fishermen.
\end{abstract}

Keywords: Adaptation of Fishermen, Environmental Changes.

\section{Introduction}

Kampung Laut was originally a name addressed to a group of people who lived and were active in the estuary area or Segara Anakan lagoon, a small sea flanked by Java and Nusakambangan Island. The community in the story lives in a stilt house on the water, so that in their daily activities they interact continuously with sea water, and to support their activities they complete with boats of varying sizes for daily activities. Finding fish is the main economic activity, and their residence is a place where fish from various regions come, lay eggs, and develop before returning to the wider ocean.

This is understandable because the Kampung Laut is a lagoon or estuary area (Sutardjo, 1985), and naturally the estuary region is a fertile area and is overgrown with various types of mangroves, nipah and sago. Coastal waters around the area are generally spawning and growth 
areas of fish, shrimp and other marine biota (nursery areas) that play a significant role in the continuity of the quantity of fish in the waters of the sea and shrimp / milkfish cultivation. In these waters, milkfish (nener) and shrimp (benur) seedlings can be captured to be raised and cultivated in shrimp ponds and milkfish ponds (Saraswati, 2004). The catch of fishermen is very much, no wonder if at that time the area was one of the popular fish producers.

When changing, the area experienced environmental degradation, in the form of narrowing and decreasing environmental quality which resulted in the decline of fish catches of the fishermen. On the one hand, environmental changes have an impact on the process of "production" of fish, while on the other hand, the number of people who catch fish is increasing so that there is over fishing or overfishing, which suppresses fish populations. Fish catches are decreasing, fishermen need to turn their brains so that their lives continue, then adaptation to the environment becomes a step that cannot be delayed because the environment is a place where humans have the opportunity to choose in order to maintain their lives.

\section{Method}

The data in this study come from direct observation of the physical conditions in Kampung Laut, especially along the Segara Anakan area as the operational base of fishermen catching fish. Observations were carried out at certain points related to community activities, interviews were also conducted to strengthen information, carried out on local communities who knew and were directly involved, both the perpetrators and other informants who understood the issue. Other data is obtained through documents that are relevant to the research objectives. The researcher also used the results of other studies that had been carried out previously to strengthen the analysis carried out.

\section{Results and Discussion}

\subsection{Kampung Laut Fishermen Facing Environmental Degradation}

The people of Kampung Laut reside along the Segara Anakan area which connects Nusakambangan Island with Java Island. For now the area looks like a big river, does not reflect the area, this is different from the previous conditions in the form of marine areas, meaning that there is a very significant change. This is based on existing data, including public testimony about the area. Information from the community said that around the year 80 to the 90s, the area, from Motean Village Ujungalang Village towards Panikel or Ujunggagak Village, which stretched was waters, not found land, but for now it has undergone changes, the area has been filled with land - arising land filled with thickets. The waters of the area are also relatively shallow and murky which causes ships to run aground in certain seasons, and only small vessels can pass. Observations in the Klaces and Ujungalang area indicate the construction of a new pier which is located in the middle several tens of meters from the old pier because the old dock has been filled with sediment (Sholeh, 2017). The community information strengthens studies conducted by several researchers that show the occurrence of environmental changes that occur in the area, both physical and social aspects such as 
narrowing and silting water areas, decreasing water quality, shrinking mangrove forest areas, and changing behavior patterns of the Kampung Laut community in the region.

Physically, the change in the Segara Anakan area was marked by the narrowing of the area due to sedimentation processes originating from the Citanduy, Kayumati, Cikujang, Cibeureum, Cikonde, Muaradua, Ujungalang and Donan Rivers. Studies conducted by ECIADB (1994, in Saputra, 2004) show that the area receives deposits every year around 3000 $000 \mathrm{~m} 3$, mostly deposited in the Segara Anakan Lagoon. As an illustration, in 1903 the area of Laguna Segara Anakan 6.450 hectares, in 1984 became 3.270 hectares, in 1992 to 1800 hectares. This means that there has been a narrowing of the area's waters since the 1980 . The increase in sedimentation at the same time informs the occurrence of land use changes in each of the upstream areas which empties into the area which encourages increased erosion and impacts on the sedimation process of the area and directly causes siltation.

The narrowing of the Segara Anakan area was compounded by the damage to the mangrove forest area. Based on the study of Ardli, et al (2015), in 1978 the area of Segara Anakan mangrove forest reached 17,090 ha and in 2004 it was 9,271.6 hectares, which meant a shrinkage of 7,819 ha for 26 years. If calculated annually, the depreciation of the area reaches $192.96 \mathrm{Ha}$ every year. Depreciation of the area of mangrove forests based on the study was caused by illegal logging $(14.23 \mathrm{~m} 3 /$ day), utilization and conversion of forest land to agriculture $(5.4 \%)$, ponds $(2.5 \%)$, settlements $(1.1 \%)$, industry $(0.4 \%)$, and other land use $(1.7 \%)$. Depreciation of mangrove areas in the area certainly reduces the function of the mangrove area as a place for spawning and nurturing various types of shrimp and fish. As a result, fish production in the region is reduced.

In contrast to the narrowing of the waters and the shrinking of mangrove forests, the waters quality of the region has also decreased. According to Djohan (2010) the decline in the quality of Segara Anakan waters was marked by the explosion of abundance of phytoplankton which was dominated by the population of Cheetoceros and Asterionella japonica in the waters of several points studied along Segara Anakan. The increase in both species is a response to the increase in $\mathrm{PO}^{4}$ content in the waters by dredging sediments in Bondan waters. Segara Anakan waters are also characterized by the presence of plankton river communities, which are as many as 19 species of phytoplankton, and 9 species of zooplankton. The decline in water quality certainly affects the number of fish populations that are usually captured by local fishermen.

\subsection{Fishermen in the Village Village at the Crossroads}

The people of Kampung Laut believe their ancestors were descendants of Mataram soldiers who came to the Kampung Laut area in order to carry out security measures in the Segara Anakan waters area from the interference of Portuguese pirates (Mulyadi, 2013). The soldiers were led by four people, namely Keep the Playa, Take Care of the Praya, Take Care of the Official and Take Care of the Sea. After the situation was safe, the Wiratamtama and his men did not return to the center of the Mataram kingdom, but stayed in the Cilacap area and surrounding areas such as Jaga Playa and Jaga Praya then settled in the area now called Klapalima, meanwhile Take Care of the Sea and Take Care of the Sea Nusakambangan Island. Keep Official in the area that is now called Legok Pari, while Jaga Laut lives in the Gebang Kuning or now better known as Kembang Kuning.

Public belief is reinforced by evidence of the existence of ancestral tombs and other legacy marks that show the existence of their ancestors. On the island the ancestors of the Kampung Laut community cultivated, utilizing existing land. Then when the Dutch came to 
power the people who lived on the island of Nusakambangan were forced to move or be displaced because the island was used as a place of detention for the prisoners. The presence of the detainees caused tremendous disruption to the local community, and was forced to move to the Segara Anakan area. Initially the community built settlements by making a house on stilts called jerambah. In those homes, people live and get to know the marine-based economy, fishing as fishermen to date.

Along with the development of time, the stage houses have changed to more permanent houses. At present most of the houses occupied by the community are permanent houses built on arising land. The community is also increasingly "nervous" about the profession of fishermen. The fishermen community is giddy because Segara Anakan is not as friendly as it used to be, which is abundant in fish, shrimp, crabs and shellfish. A lecturer who lives in Cilacap and had held KKN in Kampung Laut for a few months while still a student stated that during this activity the area was very abundant with fish, even when defecating on the river under the fish the size of a human hand was ready wait and jump. The story shows that the area is rich in fish.

Most of the current Kampung Laut fishermen are old, almost no young fishermen are found. Based on the narrative of citizens, productive age youth prefer to leave the area. They choose to work as crew members, work in factories, or work overseas. They work with companies on a contractual system, and during their work they collect money to send to families for various purposes, especially to build houses and buy motorized vehicles. No wonder the houses in the village look good because of the hard work of the youth who work outside the area. If lucky, these young people also buy land and build houses outside of Kampung Laut, especially in the city of Cilacap as an investment and prepare themselves when their children will later go to school in the city

On several occasions the Kampung Laut youths came home from Cilacap, they lived in Cilacap to join relatives or acquaintances in order to register for employment in shipping companies that opened offices in Cilacap. Overseas who managed to go back to the village to invite neighbors and relatives to follow him to work. This shows that the Kampung Laut for the younger generation is not their future, not the dream they live in, but only as a place to remember the past. Their dreams are Cilacap City and its surroundings.

\subsection{Examples of Kampung Laut Fishermen's Economic Activities}

The lack of interest in the young generation of Kampung Laut to become fishermen informs two things, first the young generation have an open mind about economic activities that they can take, without relying entirely on fishing, they have the freedom to think in determining their future according to their skills and interests as a result of the education process. Secondly, on the other hand educational institutions in the region have not succeeded in convincing the younger generation of the economic potential in the region that is feasible to be developed for their welfare. For the record, that Kampung Laut has 1 high school, namely SMAN 1 Kampung Laut. If the region that stands is a fishery vocational school in accordance with local potential, it might be a different story. Even so, there are still young people who are interested in becoming fishermen, of course they imagine becoming more modern fishermen with wider fishing operations.

a. Faithful with floating nets

Based on its operational area, fishermen in Kampung Laut are grouped into two, namely offshore fishermen and local fishermen Segara Anakan. Only a small percentage of fishermen off the ocean are looking for fish outside the waters of Segara Anakan. 
They are fishermen from Ujunggagak Village who are looking for fishermen in the south of Nusakambangan Island to Pangandaran, West Java. These fishermen use "katir" boats, which are boats equipped with balancers on the side of the boat (outrigger). Certain groups of fishermen use larger-sized vessels looking for fish far from the sea with more complete equipment, and more personnel. The fishing time is also longer, the results of fish caught are more varied, and when returning to land, usually go directly to the fish auction place, both in Cilacap and in the Pangandaran area. This category of fishermen has more capital.

Most fishermen from Kampung Laut search for fish along the Segara Anakan area. They search for fish by installing floating nets along the waters. Floating nets are fishing gear in the form of nets of a certain length equipped with buoys made of sterefoam or other materials that can float. Fishermen install floating nets according to the plots they have, they cannot install floating nets anywhere because they can conflict with other nets. There is agreement between the fishermen, wherever they may install the floating net. Installation of nets should not be close together because it will affect the other net catches. The practice of mastering the installation area is similar to land control on land, except that there is no evidence of black over white which area is in its control. If someone violates, there will be a conflict between them, and usually resolved by the local village government. Installation of floating nets is not limited by time. The main catches are fish and shrimp, catches in the form of fish are immediately handed over to collectors who also act as financiers of various needs, especially if there are damaged nets and must be replaced, these collectors provide them, thus creating an attachment to the sales chain of fishermen's catches.

b. Hunting totok shells and crabs

The high organic matter in the waters of the mangrove forest allows it to be a spawning ground, nursery (ground), and enlargement and feeding (feeding ground) of certain fish and aquatic animals. This is what causes the existence of the mangrove forest to have a very important meaning because in that region various types of fish live or stay in and out of the area along with the tides of the sea (Saraswati, 2004).

One of the catches of the fishermen of Kampung Laut is totok shells. Totok shells (Polymesoda erosa) are part of the mollusk phylum. Totok shellfish is one type of catch of fishermen who have high economic and nutritional value. Totok shells can not only be used as food ingredients, but have ecological functions, which can be used as bioindicators of heavy metals in a waters. Totok shells are often also called mangrove shells or mangrove shells from the genus Polymesoda (Geloina) is one type of shellfish that lives in the mangrove ecosystem. The right time to look for totok shells is when water begins to recede, and usually totok shells are found in muddy areas, especially sedimentary mud around mangrove forests. If the tide is high, fishermen will wait until the right time, and when the water begins to recede they rush to the location which is estimated to have many totok shells using a small size boat. They entered between mangrove plants and then got off the boat and looked for shells with their bare hands. There is no special equipment to look for totok shells, except for small boats, and must go down directly into the mud. Fishermen must be vigilant while looking for shells.

Kampung Laut is surrounded by mangrove forests, making it a habitat for mangrove crabs. These types of animals usually prefer muddy places in the mangrove forest area. $\mathrm{Crab}$ is distributed only to the litoral region with a depth range of 0-32 meters and moderate salinity. Crabs like clear areas that are free of pollution. During the day, juvenile level crabs are rarely seen in mangrove areas because they prefer to immerse 
themselves in mud or hide behind mangrove roots. Crab is a kind of non-native animal, so it will be more active at night. Marine Village fishermen make crabs as one of the catches that have high economic value. To catch the crabs they used traps which were named wadong and pintur. The trap is installed in the mangrove forest, then it will be taken back after being left for several hours. Narrowing of the mangrove forest area affects the catch of the fishermen. Mangrove crabs that have been captured are then sold to collectors, and then distributed in the sea to be processed as one of the people's favorite menus. Not surprisingly, because the economic value of crabs is very high, the crab hunting rate is also high.

c. Increasing Economic Value from Catches

Not all fishermen's catches are sold to collectors, because what must be sold to Collectors is fish with certain types and sizes. The catches in the form of small fish by fishermen are consumed by themselves, and some are reprocessed in the form of other products, one of which is shrimp paste. Terasi or belacan is a cooking spice made from shrimp or small fish which is processed in such a way through certain stages and the product is finally black and brown, sometimes added with coloring material to make it reddish. In Indonesia and other countries in Asia the existence of shrimp paste is very important, usually used to make chili sauce and flavoring in a variety of traditional recipes. Local fishermen make shrimp paste from a mixture of small shrimp and other ingredients which increases the economic value of the catch. Terasi fishery production Marine village is very typical, because it is made dry and packaged in small sizes so it is suitable for souvenirs.

Until now there has been no intensive assistance from the government to improve the quality of other processed and processed products, including in terms of raw material supply and distribution. The role of the government is very helpful to motivate and change the way people think, especially if it is associated with the wishes of the local community so that Kampung Laut becomes one of the leading tourist destinations in Cilacap given the uniqueness and distinctiveness of the region. The expected support of its form is training in production, packaging, distribution, and publication.

According to Ernes Kapp (in Suharyono, 2013) the earth is an organism and becomes a place of learning (for humans). Organisms are things that are living, animate, can develop, and not something static, or the earth is dynamic. That is, that the earth has the ability to respond or provide reciprocity from the activities of other creatures in the form of symptoms or phenomena that must be studied by humans. Every symptom, fact, pattern, or phenomenon that occurs, including in the form of changes in the landscape of the earth's surface shows that there are dynamics that have a relationship and connection with one another.

The task of humans is to learn, because humans are perfect creatures who are equipped with culture as a result of creativity, taste, and intention (Kontjaraningrat, 1990). Furthermore, Koentjaraningrat explained based on the views of several experts, that the form of culture consists of: 1) the form of culture as a complex of ideas, ideas, values, norms, rules and so on, b) the form of culture as a complex activity and patterned actions from humans in society, and c) manifestations of culture as objects of human work. Through this culture, people learn to be able to answer every challenge that exists, including the challenges of environmental change. 


\subsection{Economic Diversification as a Form of Fisherman Adaptation}

Various efforts made by fishermen to maintain their lives face changes in the environmental conditions of the Segara Anakan area. One of human strengths is the ability to adapt to changes in the environment, as well as fishermen from Kampung Laut. They also have the ability to adapt to environmental changes to maintain their lives through various efforts, including:

a. Planting on arising land and the Nusakambangan area

Sedimentation that took place in the Segara Anakan area caused the emergence of arising land. This arising land arose due to sedimentation of sand from the Citanduy river and the Cimeneng river. The more sedimentation increases every day, so it forms a large area. The existence of this arising land eventually became the target of the indigenous people of Kampung Laut and the migrants who tried to take control of this arising land. For fishermen, the presence of arising land is clearly detrimental because it reduces the catching area of fish, the fish population is also decreasing because of its narrowing habitat. The existence of arising land also caused new conflicts, where its existence was still a dispute between the community and several agencies (the ministry of law and human rights, Perhutani).

As long as the dispute takes place, the community is in fact not prohibited from working on these lands to grow crops. Actually, so far there has also been a practice of farming on the island of Nusakambangan by the people of Kampung Laut. Some residents said that they worked on land close to the location of the village with a variety of plants. What is done by the community in processing land on Nusakambangan Island is actually also known by officers, but there is no explicit prohibition, meaning that officers from the relevant ministry also understand the needs of the community. In fact, the most western part of Nusakambangan Island has been used by the community to be planted with albiso (sengon) trees which when large are cut down and then taken to the opposite side to Pangandaran area. On the edge of the island there are also some simple houses. Farming is an alternative choice for the Kampung Laut community to fulfill their needs. Changes in the landscape of the region have driven changes in the economic culture of some communities that initially from maritime economics became an agrarian economy. They learn to adapt to environmental changes. In the morning some fishermen put up floating nets then left for the next they went to the farm, and would return to the floating net to get the catch.

b. Serve boat rental

Kampung Laut is very interesting for researchers, especially those who have an interest in mangrove forest areas. For the people of Purwokerto and its surroundings, just taking a boat and going along Segara Anakan is a tour that they cannot enjoy when they are in their area, while for researchers, the area is heaven because it stores many things to know and study. For the record, mangrove forests in the Segara Anakan area are one of the largest areas in Indonesia, so it is very interesting to study, both from the physical and social aspects.

The main assets of fishermen are boats of various sizes which they call compreng boats because when they go they make a loud, loud sound. Almost all houses have boats that are operated by machines or manually (paddles). With these assets they sometimes receive orders to take guests who come for various purposes, either traveling around the mangrove area or specifically coming to the location of the "Mina Wisata" which has a tracking bridge and observation post. Boat owners also serve requests to accompany and 
accompany fishermen from Cilacap and its surroundings, the time and rental rates are also adjusted to the agreement between them, but there are indeed general standards that apply to boat rental. Orders do not come regularly, and boats that are often rented are not many because usually the request is through an intermediary, but the order can increase the income of fishermen. Especially if the fishing season is quiet, the offer from tourists or researchers who rent their boats is very helpful for the economy.

c. Fishermen and farmers

The existence of land arising in the area is still legally problematic because it becomes a material dispute or dispute between the community and several agencies. Responding to the situation, the community still took the initiative to use the existence of the arising land for various purposes, including building a residence, trying to make a pond, and raising ducks. For making ponds and raising ducks only one or two residents have tried because it seems that the community is still unsure of the business, even though based on information, the area is very suitable for raising ducks. Actually, there was once a shrimp farm business initiative in the area, but for some reason the business did not continue. The transition process from capture fishermen to aquaculture fishermen still requires process and assistance from the local government.

Kampung Laut is part of Indonesia's territory which is dominated by water, meaning that this region is part of a big dream of Indonesia as a maritime country which has an area of $6,315,222 \mathrm{Km}^{2}$, a length of coastline of the Indonesian archipelago along 99,093 km, and the number of islands that have been standardized by the National Rupture Standardization Team of 13,466 islands (BIG, 2015). Physically the changes that occur in the Segara Anakan area are the narrowing of the waters, and directly affect the changes in economic activity of the community as a manifestation of people's adaptation to their survival. However, in reality, the community is still maritime spirit that is attached to the spirit of struggle and never gives up to conquer every obstacle.

\section{Conclusion}

The community of fishing villages in the relationship between humans and the environment can be explained as those who directly receive the impact of human activities in utilizing land. The sedimentation that occurred in the Segara Anakan area reflected land use in the upper reaches of the Citanduy River, Kayumati, Cikujang, Cibeureum, Cikonde, Muaradua, Ujungalang and Donan. The contribution of the people of Kampung Laut who live and move in the waters in the environmental degradation process of the area is their activities to exploit and utilize mangrove woods to be sold to other parties, even then by some residents because they are tempted by temporary profits. In fact, people have to face environmental conditions that are not ideal for fishing because the results are decreasing to meet their daily needs.

Adaptation is a strategic step for the community to overcome the major environmental limitations in providing economic resources. The community cannot forever depend on being a fisherman because of this limitation. Diversification of economic activities is a rational step so that they can live decent lives side by side with nature where the earth is stepped on, the sky is upheld, and the sea becomes a daily friend. 


\section{References}

Erwin Riyanto Ardli, E. R, dkk (2015). Kajian Perubahan Bioekologi pada Restorasi Ekosistem Mangrove di Segara Anakan Cilacap. Jurnal Biosfera 32 (1) Januari 2015

Badan Informasi Geospasial (2015). Paradigma Geomaritim: Strategi Mewujudkan Indonesia Sebagai Poros Maritim Dunia dalam Perspektif Geografi. Jakarta. BIG-IGI

Djohan, T.S. (2010). Dinamika Komunitas Plankton di Perairan Ekosistem Hutan Bakau Segara Anakan yang Sedang Berubah. Jurnal MANUSIA DAN LINGKUNGAN, Vol. 17, No.3, Novernber 2010: 135-149

Koentjaraningrat (1990). Pengantar Ilmu Antropologi. Jakarta. Rineka Cipta

Mulyadi, S. (2013). Kisah Pergulatan Peradaban Suku Pejagan Dalam Sejarah Ingatan Kampung Laut. Cilacap: YSBS

Saputra, S.W. (2008). Biologi, Dinamika Populasi dan Pengelolaan Udang Metapenaeus elegans de Man 1907 di Laguna Segara Anakan Kabupaten Cilacap Jawa Tengah. Semarang: Badan Penerbit Universitas Diponegoro

Saraswati, A.A (2004). Konsep Pengelolaan Ekosistem Pesisir (Studi Kasus Kecamatan Ulujami, Kabupaten Pemalang, Jawa Tengah. Jurnal Teknologi Lingkungan P3TLBPPT.5 (3) 205-211

Sholeh, M. (2017). Perubahan Lingkungan dan Masa Depan Ekonomi Masyarakat Kampung Laut Kabupaten Cilacap. Jurnal Swarnabhumi Vol. 2, No. 2, Agustus 2017

Suharyono \& Amien, M. (2013) Pengantar Filsafat Geografi. Yogyakarta. Penerbit Ombak

Sukardjo, S. (1985). LAGUNA DAN VEGETASI MANGROVE. Jurnal Oseana, Volume X, Nomor 4 :128-137, 1985. ISSN 0216-1877 